\title{
Sealer Penetration and Marginal Permeability after Apicoectomy Varying Retrocavity Preparation and Retrofilling Material
}

\author{
Renata WINIK ${ }^{1}$ \\ Ângela Toshie ARAKI ${ }^{2}$ \\ José Augusto Alves NEGRÃO \\ Marina Stella BELLO-SILVA ${ }^{1}$ \\ José Luiz LAGE-MARQUES ${ }^{1,2,3}$ \\ ${ }^{1}$ Center of Research, Teaching and Clinics of Laser in Dentistry, Special Laboratory of Lasers in Dentistry (LELO); \\ ${ }^{2}$ Department of Endodontics, School of Dentistry, University of São Paulo, São Paulo, SP, Brazil \\ ${ }^{3}$ School of Dentistry, University of Taubaté, Taubaté, SP, Brazil
}

\begin{abstract}
Apicoectomy failure is generally related to inappropriate marginal sealing of the retrocavity, which allows percolation of microorganisms and their products from root canal system to periapex. This study evaluated tubular penetration of canal sealers and marginal permeability after retrocavity irradiation with Er;Cr:YSGG laser and retrofilling with MTA or cyanoacrylate. Twenty-two singlerooted teeth were decoronated and endodontically treated, their apical $3 \mathrm{~mm}$ were resected and the root ends were retroprepared with a low-speed bur. Twenty roots were randomly assigned to 4 groups $(n=5)$ : GI and GII - retrofilling with MTA and cyanoacrylate, respectively; GIII and GIV - retrocavity irradiation with Er;Cr:YSGG laser $\left(2.78 \mu \mathrm{m}, 4 \mathrm{~W}, 20 \mathrm{~Hz}, 70.8 \mathrm{~J} / \mathrm{cm}^{2}\right)$ and retrofilling with MTA and cyanoacrylate, respectively. The remaining 2 roots served as positive and negative controls. The analysis of rhodamine B dye infiltration $(\mathrm{p}=0.05)$ demonstrated that laser irradiation and MTA retrofilling presented significantly higher permeability rates $(\mathrm{p}<0.05)$. Retrofilling with cyanoacrylate showed significantly lower permeability, either when laser was used or not on retrocavity. SEM analysis depicted more cyanoacrylate penetration through dentinal tubules when compared to MTA, suggesting a more efficient marginal sealing. Based on these results, it may be concluded that cyanoacrylate provided a less permeable retrofilling regardless of the retropreparation method, suggesting a more favorable condition to the establishment of the periapical healing.
\end{abstract}

Key Words: apicoectomy, cyanoacrylate, Er;Cr:YSGG laser, MTA, retrofilling.

\section{INTRODUCTION}

Several factors inherent to the endodontic procedures can negatively affect the efficient performance of cleaning and shaping of the root canal system and lead to treatment failure. Perforations, instrument breakage, calcifications and anatomic anomalies are responsible for a possible insufficiency of the traditional endodontic treatment and, in this case, a surgical endodontic intervention is required (1) Apicoectomy plus retrograde filling is a well-established surgical procedure to treat teeth committed with persistent periapical lesion (2).

Failure of apicoectomy is generally attributed to an inappropriate marginal sealing of retrocavity, which allows percolation of microorganisms and their products from root canal system to periapex. Retrograde filling is regarded as an important procedure to seal the root end and avoid maintenance of apical infection $(3,4)$. However, exposure of dentinal tubules and lack of adaptation of filling material to retrocavity walls may jeopardize its effectiveness (5). Therefore, the study of the interaction between retrocavity preparation methods and materials used in retrofilling is an important factor to ensure therapy success.

The mineral trioxide aggregate (MTA) has been developed with the specific goal of sealing communica-

Correspondence: Prof. Dr. José Luiz Lage-Marques, Avenida Prof. Lineu Prestes, 2227, 05508-000 São Paulo, SP, Brasil. Tel/Fax: +55-113091-7839. e-mail: lage@usp.br 
tions between the root canal system and adjacent periodontal tissues (6). In previous studies, its application as a retrofilling material provided less periapical inflammation, presence of a fibrous capsule and formation of new cementum layer in contact with the material surface $(7,8)$. Likewise, many studies have indicated the potential use of cyanoacrylate in Endodontics, especially due to its sealing ability (9), biocompatibility $(10)$, and bonding property $(11,12)$.

The appropriate interaction between retrofilling material and retrocavity surface depends not only on materials characteristics, but also on the surface conditions at the time of the retrograde filling. Smear layer removal is crucial to provide a proper interface, leading to a better adaptation of the material (13). This condition can be achieved by dentin irradiation with Er;Cr:YSGG laser, which results in debris and smear layer removal. When laser is associated with a water coolant, no carbonization, melting or considerable temperature increase is observed $(14,15)$.

This study evaluated tubular penetration of canal sealers and marginal permeability after retrocavity irradiation with Er;Cr:YSGG laser and retrofilling with MTA or cyanoacrylate, thus aiming at a more effective interaction between material and retropreparation method, and consequently, an optimal apical sealing.

\section{MATERIAL AND METHODS}

Twenty-two extracted human permanent teeth with a single root canal were used. The crowns were removed at the level of the cementoenamel junction and root cervical thirds were debrided with no. 3 Gates Glidden drills (Dentsply/Maillefer, Ballaigues, Switzerland) to standardize access to the canal. The working length was established $2 \mathrm{~mm}$ beyond the apical foramen with a size $15 \mathrm{~K}$-file (Dentsply/Maillefer). The root canals were instrumented up to a size $40 \mathrm{~K}$-file and irrigated with $3 \mathrm{~mL}$ of $1 \% \mathrm{NaOCl}$ (Fórmula \& Ação, São Paulo, SP, Brazil) at each file change. The canals received $10 \mathrm{~mL}$ of $17 \%$ EDTA-T (Fórmula \& Ação) as final flush, were dried with paper points and filled $2 \mathrm{~mm}$ beyond the apex with vertically condensed gutta-percha and AH Plus canal sealer (Dentsply De Trey, Konstanz, Germany). Apical root resections were performed on all roots by removing $3 \mathrm{~mm}$ of each apex at 90 degrees to the long axis of the tooth with a no. 701 fissure bur (Dentsply/Maillefer) in a high-speed handpiece with water coolant.

Root-end cavities were shaped with a low-speed round no. 2 Carbide bur (Dentsply/Maillefer) to $3 \mathrm{~mm}$ depth. Twenty specimens were randomly assigned to 4 groups of five roots each: GI - retrofilling with MTA (Angelus, Londrina, PR, Brazil); GII - retrofilling with cyanoacrylate (Super Bonder ${ }^{\circledR}$, Loctite Henkel, Itapevi, SP, Brazil); GIII - retrograde cavity irradiation with Er;Cr:YSGG laser and retrofilling with MTA; Group IVretrograde cavity irradiation with Er;Cr:YSGG laser and retrofilling with cyanoacrylate.

The laser used in this study was a Waterlase Millenium Er;Cr:YSGG laser system (Biolase Technology Inc., San Clemente, CA, USA; Center of Research, Teaching and Clinics of Laser in Dentistry, LELO, Brazil - Project CEPID/FAPESP 98/14270-8) at $2.78 \mu \mathrm{m}$, output energy of $200 \mathrm{~mJ}$, output power of $4 \mathrm{~W}$, energy density of $70.8 \mathrm{~J} / \mathrm{cm}^{2}$ at the distal end of the fiber, repetition rate of $20 \mathrm{~Hz}$ and $75 \%$ air pressure level and $80 \%$ water level. The delivery system consisted of a fiber optic tube terminated by a sapphire crystal tip of $600 \mu \mathrm{m}$ diameter and $4 \mathrm{~mm}$ length. There was a single perpendicular irradiation of $5 \mathrm{~s}$ each, with scanning movements and $2 \mathrm{~mm}$ away from the target surface.

The retrograde cavities of GI and GII were filled with 17\% EDTA-T for $2 \mathrm{~min}$ and irrigated with $3 \mathrm{~mL}$ of saline before filling procedures. The retrograde cavities of GIII and GIV were irrigated with $3 \mathrm{~mL}$ of saline only. All root-end cavities were aspirated, dried with absorbent paper points and filled with MTA or cyanoacrylate, according to the group to which they belong. MTA was inserted into the cavity with a no. 1 spatula, condensed until the apical level and burnished with the use of a burnisher. Cyanoacrylate was minutely inserted until retropreparation was completely full.

The two remaining roots were prepared as follows: one root with retropreparation received no retrograde filling and was used as positive control ; the other root without retropreparation had the entire root surface covered with two coats of cyanoacrylate and was used as negative control.

All roots were fixed perpendicularly to a plate of wax with apexes up. A coat of cyanoacrylate was then applied on the whole surface of each root, except on the end of the roots where retrograde filling was performed. They were later immersed in 1\% rhodamine B (Fórmula \& Ação) for $24 \mathrm{~h}$, after which the roots were rinsed under tap water and dried with gauze. The roots had one 
of the proximal faces sanded under tap water, gradually increasing sandpaper grit $(600,1200$ and 4000 grit $)$ until the canal and its contents were completely exposed.

Dye penetration area was photographed. The images obtained were digitized and the linear length of the stained area between dentin surface and retrofilling material was measured using an image-analysis software (ImageLab; Softium, São Paulo, SP, Brazil) to determine permeability rates of each group. The values obtained were thereafter submitted to statistical analysis. The test for normality indicated that the values were normally distributed. Therefore, ANOVA (parametric analysis of variance) was used to verify the occurrence of statistically significant values. Multiple comparisons were done by Tukey's post-hoc test to identify the significant differences among the groups. Significance level was set at $5 \%$.

The specimens were then cleaned for $1 \mathrm{~min}$ in phosphoric acid diluted in saline and subsequently washed with sterile saline. They were dehydrated in a graded series of ethanol, mounted in stubs, sputtercoated with gold and observed by scanning electron microscopy using a JEOL JSM-6100 microscope (Jeol Ltd., Tokyo, Japan). retrocavities (GIII) when compared to non irradiated (GI). In specimens retrofilled with cyanoacrylate, no statistically significant difference was found between both methods of retrocavity preparation, bur (GII) or laser (GIV). The retrograde cavities prepared without laser irradiation and retrofilled with MTA presented significantly more permeability $(\mathrm{p}<0.05)$ than those retrofilled with cyanoacrylate.

Likewise, specimens irradiated with Er;Cr:YAGG

Table 1. Marginal infiltration means $(\mathrm{mm})( \pm \mathrm{SD})$ of rhodamine B dye.

\begin{tabular}{lcc}
\hline $\begin{array}{l}\text { Retrofilling } \\
\text { material }\end{array}$ & \multicolumn{2}{c}{ Retropreparation method } \\
\cline { 2 - 3 } & $\begin{array}{c}\text { EDTA-T } \\
\text { irrigation }\end{array}$ & $\begin{array}{c}\text { Er;Cr:YSGG laser } \\
\text { irradiation }\end{array}$ \\
\hline MTA & $39.51 \pm 4.95 \mathrm{a}$ & $157.03 \pm 13.85 \mathrm{~b}$ \\
Cyanoacrylate & $1.94 \pm 3.15 \mathrm{~cd}$ & $7.50 \pm 4.62 \mathrm{~d}$ \\
\hline
\end{tabular}

Different letters indicate statistically significant difference at $5 \%$.

\section{RESULTS}

The data used to determine the results in this study were the millimeters counted in the stained area of each tooth. Means and standard deviations were calculated (Table 1). Figure 1 shows the scanning electron microscopic analysis of retrofilling material tubular penetration in the 4 groups.

The positive control showed dye leakage throughout the length of the canals, while the negative control had no dye penetration.

In the groups in which retrocavities were filled with MTA, significantly higher permeability $(\mathrm{p}<0.05)$ was found in the irradiated

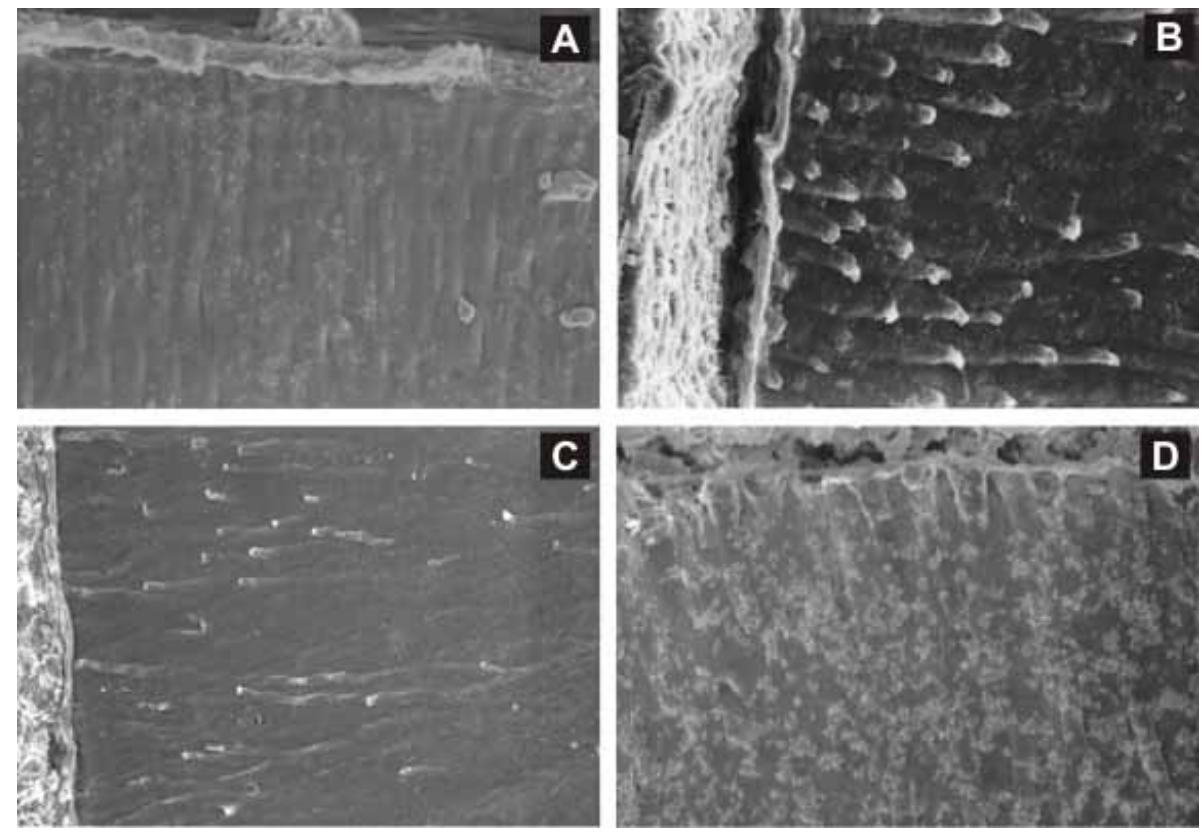

Figure 1. SEM micrographs of retrofilling material tubular penetration in the experimental groups. A: Group I - retrocavity irrigated with EDTA-T and retrofilled with MTA; B: Group II - retrocavity irrigated with EDTA-T and retrofilled with cyanoacrylate; C: Group III - retrocavity irradiated with Er;Cr:YSGG laser and retrofilled with MTA; D: Group IV - retrocavity irradiated with Er;Cr:YSGG laser and retrofilled with cyanoacrylate. 
laser and retrofilled with MTA showed significantly higher permeability rates $(p<0.05)$ than cyanoacrylate. To summarize, cyanoacrylate had the lowest rates of dye penetration, independent of the retropreparation method, whereas MTA presented higher rates, especially when retrocavities were irradiated with Er;Cr:YAGG laser.

SEM examination of MTA retrofilling depicted lack of continuity in the union between material and cavity surface and great amount of porosity. This interface presented even more discontinuity when laser was used on retrocavity before retrofilling. The SEM micrographs of cyanoacrylate groups showed more union between the retrofilling material and dentin surface in comparison to MTA, thus suggesting a more efficient sealing of the dentinal tubules (Fig. 1).

\section{DISCUSSION}

In case of failure of traditional endodontic treatment, the performance of parendodontic surgery followed by retrograde filling is needed to inhibit leakage of irritants from root canal system to periradicular tissues. The placement of a root-end filling material should provide an efficient apical sealing. Treatment prognosis partially depends on the conditions in which the retrograde filling is done (16). Thus, retrofilling requires an ideal material, which, in addition to being able to adhere to cavity walls and maintain the sealability for a long period, has also to be easy to mix, non-toxic, biocompatible, nonabsorbable, radiopaque, dimensionally stable and not affected by the presence of moisture (17).

In the present study, root-end cavities were prepared with bur and their surfaces were treated with EDTA-T or laser. The use of demineralizing irrigating solutions like EDTA-T has been reported for cleaning of root canals due to their action on the inorganic portions of the canals contents, thus increasing dentin permeability and enabling a freer passage of medications and solutions through the dentin tubules (18). Dentin irradiation with Er;Cr:YSGG laser also increases the number of open dentinal tubules and root dentin permeability. This laser is highly absorbed by water, causing microexplosions of the water content of dentin, which results in debris and smear layer removal (14).

The penetration of dentinal tubules by canal sealers was evaluated through the analysis of SEM micrographs obtained from the interface between retro- grade cavity and filling material. In the present study, slight tubular penetration was noticed in the groups retrofilled with cyanoacrylate, whereas penetration of MTA was not apparent. Dentin surface irradiation with Er;Cr:YSGG laser creates a rough and irregular morphology with open and wide dentinal tubules. This fact may have affected the marginal sealability of MTA, which was not capable of filling the irregularities present on the irradiated surface, probably because of its high viscosity. Thus, the interface between the MTA and the lased surface was interrupted in several areas, and gaps indicating this inappropriate integration were observed. The retropreparation with bur and EDTA-T presented better results than with laser, as that method of cavity preparation probably maintained the regularity of the dentin surface and facilitated material adaptation. MTA permeability rates were higher than cyanoacrylate $(p<0.05)$. These results are in accordance with those of Kairalla et al. (19), who reported an evident failure of MTA adaptation to cavity surface.

Differently from the results observed for MTA, open dentinal tubules caused by laser irradiation may have been important to allow the efficient sealability of cyanoacrylate. Its bonding and more flowable characteristics may have increased material infiltration through dentinal tubules, thus resulting in significantly lower rates of dye penetration. The same bonding and leaking properties of cyanoacrylate led to favorable results for specimens retroprepared with bur and EDTA-T. Comparison between both groups did not show statistically significant difference. Although dentinal tubules are wider in lased dentin surfaces, cyanoacrylate was also able to penetrate into dentinal tubules previously cleaned by the EDTA-T. This infiltration depths may have been different from each other according to the method applied for retropreparation. However, as the rates of permeability were not significantly different, the sealability may be more related to the presence of material penetration into dentinal tubules than to the depth of this penetration. The use of cyanoacrylate as retrofilling material was discussed elsewhere, and the same promising results could be equally observed $(5,10)$.

With the development of materials and techniques, and the use of appropriate instruments especially created for this purpose, further research are expected to indentify better results regarding the apical marginal sealability related to retrograde treatment mode.

The results of this study showed that cyanoacry- 
late had lower rates of marginal permeability and more tubular penetration, independently of the retropreparation method. Therefore, it is suggested that its use for apical retrograde filling after apicoectomy would provide a more favorable condition to the development of the expected periapical healing.

\section{RESUMO}

O insucesso das cirurgias apicais é geralmente atribuído ao selamento marginal inadequado das retrocavidades, caracterizado pelo contato ineficiente entre o material retrobturador e a superfície dentinária, o que acaba por permitir a percolação de microorganismos provenientes do canal radicular para a região do periápice. Este trabalho teve como objetivos a análise da penetrabilidade tubular de materiais retrobturadores e a avaliação da permeabilidade marginal dentinária após irradiação das retrocavidades com laser de Er;Cr:YSGG e retrobturação com MTA ou cianoacrilato. Vinte e dois dentes humanos unirradiculares tiveram a coroa seccionada, foram tratados endodonticamente e tiveram os $3 \mathrm{~mm}$ apicais removidos. As retrocavidades foram preparadas com broca em baixa rotação. Vinte raízes foram aleatoriamente divididas em 4 grupos $(n=5)$ : GI e GII - retrobturação com MTA e cianoacrilato, respectivamente; GIII e GIV - retrocavidades irradiadas com laser de Er;Cr:YSGG $\left(2,78 \mu \mathrm{m}, 4 \mathrm{~W}, 20 \mathrm{~Hz}, 70,8 \mathrm{~J} / \mathrm{cm}^{2}\right)$ e retrobturação com MTA e cianoacrilato, respectivamente. As duas raízes restantes atuaram como controles positivo e negativo. A análise da infiltração do corante rodamina $B(p=0,05)$ demonstrou que a irradiação com laser e a retrobturação com MTA apresentaram níveis de permeabilidade significantemente maiores $(p<0,05)$. A retrobturação com cianoacrilato proporcionou níveis de permeabilidade significantemente menores em ambas as situações (EDTA-T ou laser). A análise das micrografias revelaram maior penetração tubular do cianoacrilato quando comparado ao MTA, indicando um selamento marginal mais eficiente. De acordo com os resultados obtidos, foi possível concluir que o cianoacrilato promoveu uma menor permeabilidade da retrobturação, independentemente do método utilizado para o retropreparo, sugerindo, portanto, uma condição mais favorável ao estabelecimento da reparação periapical.

\section{ACKNOWLEDGEMENTS}

The authors would like to express their gratitude to the Center of Research, Teaching and Clinics of Laser in Dentistry, Special Laboratory of Lasers in Dentistry - LELO, at the University of São Paulo (Brazil).

\section{REFERENCES}

1. Bernabé PFE, Holland R, Morandi R, Souza V, Nery MJ, Otoboni JA, Dezan EJ, Gomes-Filho JE. Comparative study of MTA and other materials in retrofilling of pulpless dogs' teeth. Braz Dent J 2005;16:149-155.

2. Aqrabawi J. Sealing ability of amalgam, super EBA cement, and MTA when used as retrograde filling materials. Braz Dent J 2002;188:266-268.

3. Gilheany PA, Figdor D, Tyas MJ. Apical Dentin Permeability and Microleakage Associated with Root End Resection and Retrograde Filling. J Endod 1994;20:22-26.

4. Ennes J, Lage-Marques JL. Qualitative analysis of some retrofilling materials - an in vitro study. Rev Pós Grad 2000;7:57-63.

5. Rud J, Andreasen JO. A study of failures after endodontic surgery by radiographic, histologic and stereomicroscopic methods. Int J Oral Surg 1972;1:311-328.

6. Torabinejad M, Watson TF, Pitt Ford TR. Sealing ability of Mineral Trioxide Aggregate when used as a root end filling material. J Endodon 1993;19:591-595.

7. Holland R, de Souza V, Murata SS, Nery MJ, Bernabe PF, Otoboni Filho JA, Dezan Junior E. Healing Process of dog dental pulp after pulpotomy and pulp covering with mineral trioxide aggregate or Portland cement. Braz Dent J 2001;12:109-113.

8. Pitt Ford TR, Torabinejad M, McKendry DJ, Hong CU, Kariyawasan SP. Use of mineral trioxide aggregate for repair of furcal perforations. Oral Surg Oral Med Oral Pathol 1995;79:756-762.

9. Barkhordar RA, Javid B, Abbasi J, Watanabe LG. Cyanoacrylate as a retrofilling material. Oral Surg Oral Med Oral Pathol 1988;65:468-473.

10. Azevedo CL, Marques MM, Bombana AC. Cytotoxic effects of cyanoacrylates used as retrograde filling materials: an in vitro analysis. Braz Oral Res 2003;17:113-118

11. Lage-Marques JLS, Conti R, Antoniazzi JH. The use of histoacryl in Endodontics. Braz Dent J 1992;3:95-98.

12. Azevedo CL, Lage-Marques JL, Rode SM. Sealing quality of Histoacryl when compared to amalgam as retrofilling. J Endod 1996;22:211.

13. Deus G, Gurgel Filho ED, Ferreira CM. Coutinho Filho T. Intratubular penetration of root canal sealers. Braz Oral Res 2002;16:332-336.

14. Ishizaki NT, Matsumoto K, Kimura Y, Wang X, Kinoshita J, Okano SM, Jayawardena JA. Thermographical and morphological studies of Er,Cr:YSGG laser irradiation on root canal walls. Photomed Laser Surg 2004;22:291-297.

15. Miller RJ. Treatment of the contaminated implant surface using the Er,Cr:YSGG laser. Implant Dent 2004;13:165-170.

16. Trope M, Lost C, Schmitz HJ, Friedman S. Healing of apical periodontitis in dogs after apicoectomy and retrofilling with various filling materials. Oral Surg Oral Med Oral Pathol Oral Radiol of Endodon 1996;81:221-228.

17. Adamo HL. A comparison of MTA, Super-EBA, composite and amalgam as root end filling materials using a bacterial microleakage model. Int Endod J 1999;32:197-203.

18. Foster KH, Kulild JC, Weller RN. Effect of smear layer removal on the diffusion of calcium hydroxide through radicular dentin. J Endod 1993;19:136-140.

19. Kairalla EC, Labate JB, Prado TST, Lage-Marques JL. Scanning electron microscopic analysis of the adaptation of retrofilling materials. Rev Pós Grad 1997;4:311.

Accepted August 30, 2006 